\title{
Effect of Cassava Intercropping with Legume Crops Followed by Sorghum on Growth, Yield and Yield Parameters of Cassava-Based Double Cropping System
}

\author{
Gebisa Benti ${ }^{*}$, Gezu Degafa, Mohammed Jafar, Habte Birhanu \\ Department of Horticulture, Fadis Agricultural Research Center, IQQO, Harar, Ethiopia
}

Email address:

bantiig@gmail.com (G. Benti)

${ }^{*}$ Corresponding author

\section{To cite this article:}

Gebisa Benti, Gezu Degafa, Mohammed Jafar, Habte Birhanu. Effect of Cassava Intercropping with Legume Crops Followed by Sorghum on Growth, Yield and Yield Parameters of Cassava-Based Double Cropping System. Plant. Vol. 8, No. 2, 2020, pp. 37-42.

doi: 10.11648/j.plant.20200802.13

Received: March 24, 2020; Accepted: May 11, 2020; Published: July 30, 2020

\begin{abstract}
Some lowland farmers of eastern Harerghe survive with some grain support from government and different NGOs due to shortage of rainfall and prevalence of drought. In Harerghe, intercropping is well practiced and most of farmers intercrop Khat with sorghum and groundnut, but single production per year. To these gaps the experiment was proposed and conducted under rainfed conditions at Fedis Agricultural Research Center of Oromia Agricultural Research Institute (OARI) at Boko sub-site, eastern Ethiopia to determine the compatibility of crops in double cropping system and efficient land use for the component crops. Experimental was conducted in two phases: cassava (Variety Kello) with legumes (soybean, haricot bean and cowpea) and cassava based sorghum varieties (Hormat, Gedo and Birhan) in one cropping season. The treatments were arranged as intercropping and sole cropping. A total of 7 treatments for preceding and 7 treatments for cassava-based succeeding treatments were arranged in completely randomized block design with three replications. Variety Kello was used for the experiment. The results revealed that there were significant $(\mathrm{P}<0.05)$ differences for cassava average root weight, number of roots per plant, root diameter and root yield due to cassava-legumes intercropping. Soybean-cassava intercropping increased average root weight, root numbers and root enlargement of cassava by $39,33.6$ and $27.7 \%$ as compared to cassavacowpea intercropping. Cowpea intercropping in cassava was significantly affected cassava root yield as compared to other legumes intercrop. Cassava-soybean intercropping was increased root yield by 41.7 and $21.3 \%$ as compared to cassava-cowpea and cassava-haricot bean, respectively. Cassava-soybean intercropping improved land use efficiency by 16.4 and $19.3 \%$ as compared to cassava-cowpea and cassava-haricot bean intercropping, respectively. Accordingly, pure stands could required 74 , 40 and $46 \%$ more land i.e. the mixture cropping gives 74,40 and $46 \%$ yield advantage, for soybean, haricot bean and cowpea, respectively, as intercropped in cassava than the pure stand. Following the harvest of legumes, sorghum was sown as double crop for additional yield advantage. The highest organic matter and total nitrogen was recorded for the pure stand plot of cassava followed by cassava-soybean intercropping. Therefore, from this result view, cassava-soybean intercropping following cassava-based early maturing sorghum was recommended for the study area and similar agro ecologies.
\end{abstract}

Keywords: Cassava, Cowpea, Haricot Bean, Intercropping, Sorghum, Soybean

\section{Introduction}

Cassava (Mahinot esculenta Cratzy) is a perennial crop native to tropical America with its center of origin in northeastern and central Brazil [2]. It is one of the most important food energy sources in many tropical countries [5]. It is cultivated mainly for its enlarged starchy roots and one of the most important food staples in the tropics, where it is the fourth most important energy source [3]. Its roots are the main source of calories to approximately 600 million people in Africa, Asia, Latin America and Oceania. On the world wide basis it ranks as the sixth most important source of calories in the human diet [10]. Given the crop's tolerance to poor soil and harsh climatic conditions, it is generally 
cultivated by small-scale farmers as a subsistence crop in a diverse range of agricultural and food systems. Roots can be left in the ground without harvesting for a long period of time, making it a useful crop as security against famine.

Cropping system aim at making efficient use of growth resources so that high and /or stable productivity can be achieved [22, 24]. Multiple cropping is the most common traditional cropping system in tropical Africa. It provides the farmer with a variety of returns from the land often increases the efficiency of resource utilization by combining variety of crops and reduces the risk of dependence on a single crop which may suffer from environmental or economic fluctuations. It also gives scope for increased labor use efficiency and provides early income [26]. System involving cassava is the most common throughout the humid and subhumid regions of Africa.

Cassava is well suited to intercropping with short duration crops because of its initial slow growth as well as its length of stay in the field (12 to 18 months). In some country of Africa, it is commonly grown in association with crops like maize which exploits the micro-environment early in the growing season and melon a low canopy crop that serves a dual purpose of protecting the soil against erosion and for weed control. The crops are selected on the basis of differences in growth habits and can be combined in either simple or complex mixtures. Complex mixtures consisting of three or more crop species are known to give higher financial and caloric returns [13]. Cassava is often left scattered in the field to mature after the other crops have been harvested [7]. However, it has been observed that the fields become very weedy and, while a few farmers carry out weeding after harvesting the early season crops, some plant a few stands of okra and other vegetables in the cassava farm in the late season [14]. Cropping could possibly be intensified with appropriate plant arrangement on the field and by modifying cassava canopy in order to introduce a late season crop like cowpea and beans. This will not only increase the productivity of the land, but will also prevent weed from taking over. Other reports disagree with this [4, 15, 17]. However, legume crops as a source of rich protein are particularly important if incorporated into the diets of cassava-consuming populations.

Limited availability of additional land for crop production, decreased soil fertility and declining yield for major food crops have been cited as the major concerns for agriculture's ability to provide nourishment for the increasing population [27]. An advantage commonly claimed for intercropping systems is that, they offer greater yield stability than sole cropping [16]. The system of intercropping is to a great extent practiced in various ways based on the extent of spatial arrangement of the crops on the field [21]. For subsistence farmers, greater stability in the production of food crops in inter-cropping systems is particularly meaningful, since this characteristic of the production system tends to better insure their sustainability and substantially reduces the risk of total crop loss.

In Harerghe, intercropping is well practiced and most of farmers intercrop Chat with sorghum and groundnut, but single production per year. Some lowlands of eastern part of Harerghe survive with some grain support from government and different NGOs due to shortage of rainfall and prevalence of drought. To such area it is important to adapt some technologies that can tolerate the agro-ecology and increase production per unit land, especially through intercropping and double cropping using early maturing crops through adjusting with the agro-ecology of the area. Therefore, intercropping of cassava with legumes crops following early maturing sorghum is an important method in increasing production per unit land area.

The limitations of these agricultural inputs and rising pressure on the supply of arable land of the Harerghe regions may lead to more intensive mono cropping of sorghum. Currently, farmers developing different farming system from the effort of research scientists and agricultural experts. The only way to increase agricultural production in the small or marginal units of farming is to increase the productivity per unit time and area. Cropping system and practices in turn could influence disease epidemics caused by populations of pathogens in populations of plants. Understanding the association of disease intensity with cropping systems, crop combinations and management practices will help to identify the most important variables and focus efforts in developing an integrated and sustainable management packages. Therefore, this study was aimed to determine the compatibility of crops in double cropping system and efficient use of land for the crops.

\section{Materials and Methods}

\subsection{Description of the Experimental Site}

The study was conducted under rainfed conditions at Fedis Agricultural Research Center of Oromia Agricultural Research Institute (OARI) at Boko sub-site, which is located at the latitude of $9^{\circ} 07^{\prime}$ north and longitude of $42^{\circ} 04^{\prime}$ east, in the middle and lowland areas and at the altitude of 1702 meter above sea level, with a prevalence of lowlands.

The soil of the experimental site is black with surface soil texture of sand clay loam that contains $8.20 \%$ organic matter; $0.13 \%$ total nitrogen, available phosphorus of $4.99 \mathrm{ppm}$, soil exchangeable potassium of $1.68 \mathrm{cmol}(+) / \mathrm{kg}$ and a $\mathrm{pH}$ value of 8.26 (Table 1). The experimental area is characterized as lowland climate. The mean rainfall is about $859.8 \mathrm{~mm}$ for the last ten years. The rainfall has a bimodal distribution pattern with heavy rains from April to June and long and erratic rains from August to October. The mean maximum and minimum annual temperature are 27.7 and $11.3^{\circ} \mathrm{C}$, respectively, for the last five years (Fedis Agriculture Research Center Metrological Station).

The total rainfall distribution during the cropping seasons were 883.8, 1022.2 and $728.7 \mathrm{~mm}$ in 2016, 2017 and 2018, respectively. Rainfall is bimodal in a year, the first rain set is from March to May and the second is from August to September. The preceding crops (Cassava + legumes) were 
planted in the first week of April during the set of rainfall and cassava based intercropped legumes were harvested in the last week of July in the first two years. The succeeding crops (cassava + sorghum), sorghum was planted with the shower of rainfall, after one week of legumes harvested in the beginning of August in the first two years.

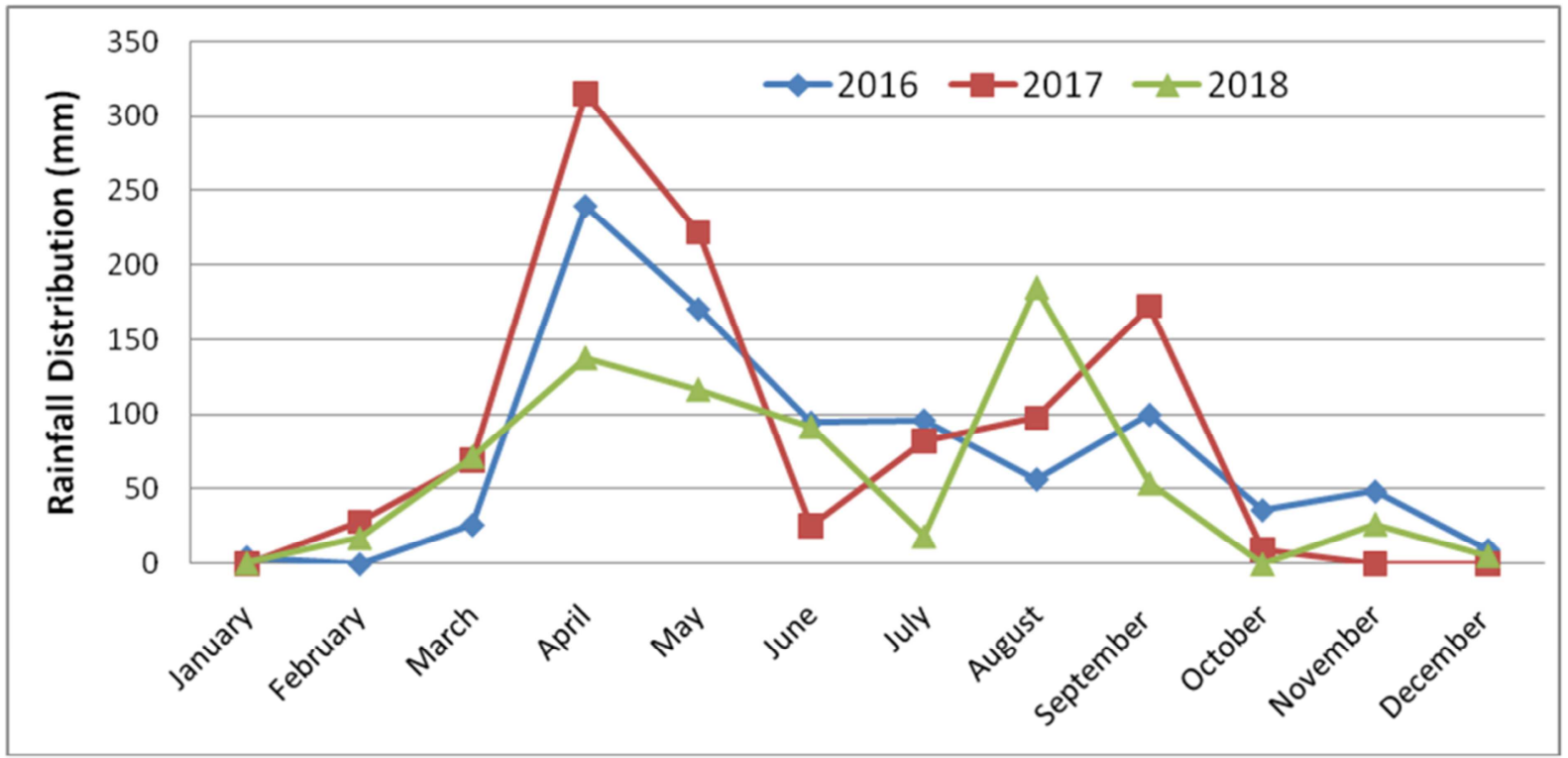

Figure 1. Rainfall distribution during the three years of cropping seasons.

\subsection{Experimental Treatments and Design}

The experiment had two phases: 1) Intercropping cassava with legumes, 2) Cassava-based intercropping early maturing and striga tolerant sorghum varieties (Gedo, Hormat and Birhan). Field experiment was conducted using 7 treatments for each phase and laid out in randomized complete block design in 3 replications. Variety Kello was used in the experiment. Cassava cuttings were planted at $1 \mathrm{~m}$ and $1.2 \mathrm{~m}$ between plants and rows, respectively. Two rows of legume crops were planted at $40 \mathrm{~cm}$ apart from cassava plant rows. Seeds of legumes (haricot bean, soy bean and cow pea) were planted at 10,5 and $10 \mathrm{~cm}$, respectively. Both crops were planted at a time during the first shower of rainfall. In the second phase after legumes harvested, sorghum varieties were sawn between cassava in two rows as in the case of legumes. Sorghum was planted $30 \mathrm{~cm}$ apart from the two rows of cassava plants and $40 \mathrm{~cm}$ spacing between the two rows of sorghum. The experiment had two cropping cycles:

Table 1. Treatment combination in both cropping cycles.

\begin{tabular}{ll}
\hline $\begin{array}{l}\text { First cropping cycle: Cassava }+ \\
\text { Legumes }\end{array}$ & $\begin{array}{l}\text { Second cropping cycle: Cassava }+ \\
\text { sorghum }\end{array}$ \\
\hline 1. Cassava +Haricot bean & 1. Cassava + Gedo \\
2. Cassava + Soybean & 2. Cassava + Hormat \\
3. Cassava + Cowpea & 3. Cassava + Birhan \\
4. Sole Cassava & 4. Sole Cassava \\
5. Sole Haricot bean & 5. Sole Gedo \\
6. Sole Soybean & 6. Sole Hormat \\
7. Sole Cowpea & 7. Sole Birhan \\
\hline
\end{tabular}

\subsection{Data Management and Statistical Analysis}

Data of each crop were taken randomly from tag plants per experimental unit (plots). The following data were collected for each crop.

Cassava data: number of branches, root length (cm), root diameter $(\mathrm{cm})$, number of root per plant, average root weight (g) and root yield $\left(\mathrm{t} \mathrm{ha}^{-1}\right)$.

Legumes data: grain yield $\left(\mathrm{kg} \mathrm{ha}^{-1}\right)$

Sorghum data: grain yield $\left(\mathrm{kg} \mathrm{ha}^{-1}\right)$

The collected data were subjected to ANOVA using GenSTAT Software version $15^{\text {th }}$ edition. Land use efficiency was determined by calculating Land Equivalent Ratio (LER) using [16] method. Land equivalent ratio of cassava is calculated as intercrop yield of cassava/pure stand yield of cassava and that of haricot bean and sorghum is calculated as intercrop yield of haricot bean and/or sorghum/pure stand yield of haricot bean and/or sorghum.

\section{Result and Discussion}

\subsection{Cassava-Legumes Intercropping on Root Yield Parameters}

The experiment was conducted to evaluate cassava-based double cropping of different component crops. The result revealed that all growth and yield parameters of cassava were significantly $(\mathrm{P} \leq 0.05)$ affected due to intercropping, except number of branches and root length. Parameters like average root weight, number of roots per plant and root diameter were statistically paired for the treatments, except for cassava-cowpea intercropping that was the lowest value for the parameters (Table 1). Cassava-cowpea intercropping was significantly affected average root weight, root numbers and root diameter. Soybean-cassava intercropping increased average root weight, root numbers and root enlargement of cassava by $39,33.6$ and $27.7 \%$ as compared to cassavacowpea intercropping. Cassava-soybean intercropping was 
increased root yield by $41.7 \%$ and $21.3 \%$ as compared to cassava-cowpea and cassava-haricot bean, respectively (Table 2). Results from [18] and [19] showed that higher cassava yield when intercropped with soybean and other beans than as a sole crop. Similarly, [11] were also reported that cassava (variety Kello) root yield of 37.18 tons ha $^{-1}$ in sole cropping at Fadis. Cassava-cowpea intercropping was significantly decreased cassava root yield as compared to other legumes intercrop as cowpea had greater leaf canopy that the other legumes and better competitor for resources as compared to other legumes. This study was in line with [25] who reported that cassava inter-cropped with cowpea decreased root yield by 11 to $17 \%$.

Table 2. Effect of cassava based-legumes-sorghum double cropping on root yield parameters of cassava.

\begin{tabular}{|c|c|c|c|c|c|}
\hline Treatments & ARW (g) & NBPP & NRPP & RD (cm) & RL (cm) \\
\hline Cassava + Soybean & $914.70 \mathrm{a}$ & 3.13 & $9.80 \mathrm{a}$ & $5.91 \mathrm{a}$ & 46.43 \\
\hline Cassava + Haricot bean & $816.50 \mathrm{ab}$ & 2.60 & $9.40 \mathrm{a}$ & $5.32 \mathrm{ab}$ & 51.93 \\
\hline Cassava + Cowpea & $557.80 \mathrm{~b}$ & 3.20 & $6.51 b$ & $4.27 b$ & 50.40 \\
\hline Sole Cassava & $862.70 \mathrm{ab}$ & 2.53 & $8.47 \mathrm{a}$ & $5.61 \mathrm{a}$ & 49.10 \\
\hline $\operatorname{LSD}(0.05)$ & 294.700 & NS & 1.935 & 1.190 & NS \\
\hline CV $(\%)$ & 18.7 & 23.5 & 11.3 & 11.3 & 14.9 \\
\hline
\end{tabular}

ARW=Average Root Weight, NBPP=Number of Branches Per Plant, NRPP=Number of Roots Per Plant, RD=Root Diameter, RL=Root Length.

\subsection{Cassava - Legumes Intercropping}

The result indicated that pure stand of haricot bean was significantly different in grain yield from intercropping of the same crop. Pure stand of haricot bean provided grain yield of $33.5 \%$ over the intercrop of the same crop. However, the grain yield of legumes intercropped with cassava was additional benefit for the cassava production land. Intercropping of soybean and cowpea with cassava did not significantly affected grain yield of same crops as compared to pure stand.
In cassava based double cropping, sorghum varieties was followed legumes and significant differences were observed between pure stand and intercrops. Pure stand of Gedo variety was significantly different from intercrop of the same crop for grain yield. However, the yield of sorghum varieties intercropped with cassava was low; it might be the competition of cassava with sorghum for moisture and or soil nutrients because of the shortage of rainfall distribution $(241.8 \mathrm{~mm}$ and $279.7 \mathrm{~mm}$, total rainfall for four months of sorghum growing life) in 2016 and 2017 cropping season, respectively.

\subsection{Cassava Based-Sorghum Intercropping}

Table 3. Effect of cassava-based legumes and sorghum double intercropping on root (tons ha $\mathrm{a}^{-1}$ ) and grain yields (kg ha ${ }^{-1}$ ) of component crops over the two years.

\begin{tabular}{llll}
\hline \multirow{2}{*}{ Treatments } & Cassava Root yield & Preceding crop & Succeeding crop \\
\cline { 2 - 4 } & & Legumes Grain yield & Sorghum grain yield \\
\hline Cassava + Soybean + Hormat & $51.36^{\mathrm{a}}$ & $1618^{\mathrm{ab}}$ & $804^{\mathrm{b}}$ \\
Cassava + Cowpea + Birhan & $29.94^{\mathrm{c}}$ & $1446^{\mathrm{b}}$ & $882^{\mathrm{b}}$ \\
Cassava + Haricot bean + Gedo & $40.40^{\mathrm{b}}$ & $1406^{\mathrm{b}}$ & $820^{\mathrm{b}}$ \\
Sole Cassava & $54.28^{\mathrm{a}}$ & -- & -- \\
Sole Haricot bean & -- & $2114^{\mathrm{a}}$ & -- \\
Sole Soybean & -- & $2018^{\mathrm{ab}}$ & -- \\
Sole Cowpea & -- & $1589^{\mathrm{ab}}$ & -- \\
Sole Gedo & -- & -- & -- \\
Sole Hormat & -- & -- & $1292^{\mathrm{a}}$ \\
Sole Birhan & -- & 453 & $1059^{\mathrm{ab}}$ \\
LSD $(0.05)$ & 9.5 & 26.5 & $1034^{\mathrm{ab}}$ \\
CV $(\%)$ & 17.8 & 254.1 & 25.7 \\
\hline
\end{tabular}

Sorghum yield was declined due to shortage of rainfall after September in both years in 2016 and 2017. However, the intercrops were significantly efficient in land use economy. In other way, aboveground sorghum stalk was also used for cattle feed as farmers' of Harerghe need different forage crops for fattening.

\subsection{Land Equivalent Ratio (LER)}

The land area and yield advantage obtained due to mixed cropping was calculated as land equivalent ratio (LER). This study showed that intercropping legumes in cassava recorded land equivalent ratio of more than 1 and was beneficial in land productivity as compared to pure stand. Accordingly, pure stands could required 74,40 and $46 \%$ more land i.e. the mixture cropping gives 76,51 and $15 \%$ yield advantage, for soybean, haricot bean and cowpea, respectively, intercropped in cassava than pure stand of these crops. Cassava-soybean intercropping improved land use efficiency by 16.4 and $19.3 \%$ as compared to cassavacowpea and cassava-haricot bean intercropping, respectively. Intercropping led to greater LER compared with sole cropping. Despite individual yields of component crops being lower under intercropping compared with sole cropping, the overall land productivity was greater under 
intercropping. Similar results have been reported across diverse environments and cropping systems [6, 9, 23].

Sorghum was cassava-based double cropped following legume crops. Intercropping cassava based double cropping was advantageous than pure stand of cassava. Sorghum grain yields was also additional benefit as it was intercropped in cassava following the legume crops. The result showed that sorghum intercropping in cassava following legume crops was advisable. Because sorghum benefited additional income from the bare space in cassava and even used as forage if offset of rain occurred as farmers were demanded for cattle feed as expense of grain yield.

Table 4. Land equivalent ratio of legume crops and cassava intercropped in the first cropping cycle.

\begin{tabular}{lllll}
\hline Legumes & Sole crop & Intercrop & Partial LER $_{\mathbf{L}}$ & Partial LER $_{\mathbf{C}}$ \\
\hline Soybean & 2018 & 1618 & 0.802 & 0.946 \\
Haricot bean & 2114 & 1406 & 0.665 & 0.744 \\
Cowpea & 1589 & 1446 & 0.910 & 0.551 \\
\hline
\end{tabular}

$\mathrm{LER}_{\mathrm{L}}=$ Land Equivalent Ratio of Legumes, $\mathrm{LER}_{\mathrm{C}}=$ Land Equivalent Ratio of Cassava

Table 5. Land equivalent ratio of sorghum varieties and cassava intercropped in the second cropping cycle.

\begin{tabular}{|c|c|c|c|c|c|}
\hline Sorghum & Sole crop & Intercrop & Partial LER & Partial LER $_{\mathrm{C}}$ & LER \\
\hline Hormat & 1058.5 & 803.7 & 0.759 & 0.946 & 1.705 \\
\hline Gedo & 1292.3 & 820 & 0.634 & 0.744 & 1.378 \\
\hline Birhan & 1033.8 & 881.5 & 0.852 & 0.551 & 1.403 \\
\hline
\end{tabular}

$\mathrm{LER}_{\mathrm{S}}=$ Land Equivalent Ratio of Sorghum, $\mathrm{LER}_{\mathrm{C}}=$ Land Equivalent Ratio of Cassava

\subsection{Soil Fertility Improvement}

Mixture cropping lead to the competition of moisture and nutrients in the soil among the crops. However, cropping of non-nitrogen fixing crops with nitrogen fixing legume crops can improve soil fertility. The highest organic matter and total nitrogen was recorded for the pure stand plot of cassava followed by cassava-soybean intercropping. Cassava pure stand plot did not have competitor for nutrients why the nutrients were high in the plot as compared to other plots. Accordingly, the soil of these two plots were good structural condition and high structural stability [8] that might increased root yield of cassava. According to this study the highest competitor for nutrients was cowpea intercropped in cassava following haricot bean. This result was in line with the study of [20] who reported that cassava-cowpea intercropping was better competitor for resources compared as to other legumes. The phosphorous was very low across all plots according to the range of [12] and high exchangeable potassium [1].

Table 6. Plots based soil chemical analysis.

\begin{tabular}{llllllll}
\hline S/N & Sampling plots & EC & OM & pH & TN & Avail. P & Exch. K \\
\hline 1 & Cassava + Soybean & 0.17 & 4.01 & 7.10 & 0.24 & 2.72 & 129.00 \\
2 & Cassava + Haricot bean & 0.14 & 3.01 & 8.30 & 0.15 & 4.52 & 125.50 \\
3 & Cassava + Cowpea & 0.19 & 2.53 & 8.15 & 0.13 & 9.00 & 123.00 \\
4 & Sole Cassava & 0.17 & 4.37 & 8.18 & 0.25 & 5.52 & 129.50 \\
5 & Sole Soybean & 0.14 & 4.18 & 8.30 & 0.16 & 1.08 & 125.00 \\
6 & Sole Haricot bean & 0.15 & 3.82 & 8.10 & 0.17 & 1.28 & 127.00 \\
7 & Sole Cowpea & 0.15 & 2.73 & 7.88 & 0.13 & 1.72 & 127.00 \\
\hline
\end{tabular}

$\mathrm{pH}$ (soil to water ratio 1:25) by $\mathrm{pH}$ meter, EC (soil to water ratio 1:25) by electro conductivity meter, OM (Organic Matter by\%), Exch. $\mathrm{K}_{(\mathrm{cmol}}(+) \mathrm{kg}^{-1}$ soil), Avail. P (mg kg${ }^{-1}$ soil), TN (Total Nitrogen by\%).

\section{Conclusion and Recommendation}

Incorporation of grain legumes into the cassava-based cropping systems could enhance overall productivity of the systems in this dry environment of east Harerghe zone. In this study soybean intercropped in cassava did not affect the root yield of cassava. Intercropping soybean in cassava advanced about $74 \%$ yield advantage, that means the pure stand could required $74 \%$ more land as compared to the mixture. Intercropping also improve soil fertility in addition to diversifying different crops. Intercropping soybean with cassava showed less competition and improved soil structure as compared to other legume crops. Cassava also did not significantly affected grain yield of soybean intercropped in cassava as compared to pure stand of soybean. Because of the long duration of cassava roots maturity, drought and disease problems, intercropping grain and legumes in cassava should be developed. Producing cassava for dual-purpose as root yields, and hay is a good fodder for dairy cows. Cassava tuber is very low in protein and inclusion of a pulse crop is quite significant from the point of view of balanced nutrition in Harerghe. Therefore, from this result view, cassava-soybean intercropping following early maturing sorghum was recommended for the study area and similar agro ecologies. 


\section{Acknowledgements}

The authors greatly indebted to acknowledge the Oromia Agricultural Research Institute for funding the study. Our heartfelt thanks also go to all staff members of the Fedis Agricultural Research Center for their support in ideas and facilitation for the success of this study. We also inspire to thanks Mr. Murtessa Yusuf for his assistance in data recording and facilitation.

\section{References}

[1] Abbott, T. S. (Ed.) (1989). BCRI soil testing methods and interpretation. NSW Agriculture and Fisheries, Rydalmere, NSW.

[2] Allem, A. C. 2002. The origin and taxonomy of cassava. In: R. J. Hillocks, M. J. Boulder (Eds.). CO, USA, p. 191.

[3] Alves, A. A. A. 2002. Cassava botany and physiology. In: R. J. Hillock, J. M. Thresh, A. C. Bellotti (Eds). Cassava: Biology, Production and Utilization, CABI International Oxford, pp. 67-89.

[4] Balasubramanian, V. and Sekayange, L. 1990. Area harvest equivalency ratio for measuring efficiency in multi-season intercropping. Journal of Agronomy, 82: 519-522.

[5] Cock, J. H. 1985. Cassava: New potential for a neglected crop. West view Press, R. J. Hillock, J. M. Thresh, A. C. Bellotti (Eds). Cassava: Biology, Production and Utilization, CABI International, Oxford, pp. 1-16.

[6] Dapaah, H. K., Asafu-Agyei, J. N., Ennin, S. A., Yamoah, C., 2003. Yield stability of cassava, maize, soya bean and cowpea intercrops. J. Agric. Sci. 140, 73-82.

[7] Edje, O. T. 1982. Comparative development and yield and other agronomic characteristics of maize and groundnut in monoculture and association. In: Proceedings of the $2^{\text {nd }}$ symposium on intercropping in semi-arid areas. Keswani, C. I. and Ndurguru, B. J. (eds), PP. 401. Morongoro, Tanzania.

[8] Emerson, W. W. (1991). Structural decline of soil, assessment and prevention. Australian Journal of Soil Research 29, 905922.

[9] Ennin, S. A., Dapaah, H. K., 2008. Legumes in sustainable maize and cassava cropping systems in Ghana. Agric. Food Sci. J. Ghana 7, 519-540.

[10] Food and Agricultural Organization (FAO). 1999. Crops and products and domain. Available online at: www.apps.fao.org/lim500/nph-wrap.pl FS.

[11] Gebisa Benti and Gezu Degefa, 2017. "Performance Evaluation and palatability taste of cassava varieties in Fedis and Babile districts, Eastern, Ethiopia”, International Journal of Current Research, 9, (04), 48570-48575.

[12] Holford, I. C. R., and Cullis, B. R. 1985. Effects of phosphate buffer capacity on yield response curvature and fertiliser requirements of wheat in relation to soil phosphate tests. Australian Journal of Soil Research 23, 417-427.
[13] IITA. 1990. Cassava in Tropical Africa. A References Manual International Institute of Tropical Agriculture. Ibadan, Nigeria, 176 PP.

[14] Isola. O. T. 1998. Effects of cassava planting patterns, pruning regimes and fertilizers on growth and yield of cassava/maize/melon and relayed cowpea. A PhD Thesis. Department of Agronomy, University of Ibadan, Nigeria: 189 pp.

[15] Keating, B. A., Evenson, J. P., and Fukai, S. 1982. Environmental effects on growth and development of cassava (Manihotesculenta Crantz). III. Assimilated distribution and storage organ yield. Field Crops Res. 5: 293-303.

[16] Mead, R. and Willey, R. W. 1980. The concept of a 'land equivalent ratio' and advantages in yield from intercropping. Experimental Agriculture, 16, 217-218.

[17] Mason, S. C., Leihner, D. E., and Vorst, J. J. 1986. Cassava with cowpea; and cassava with peanut intercropping. I. Yield and land use efficiency. Journal of Agronomy. 78: 43-46.

[18] Neumann, I. F. 1984. La promotion des cultures associees au projet. Etudes et Experiences, No. 4: 80 pp.

[19] Nyabyenda, P. 1983. Association de patatedouce et du manioc avec d'autrea cultures. In Culture et Selection du Manioc et de Patate Douce au Rwanda, 1983, Ndamage, G. et al., eds. Compterendu, Rwanda, Institut des Sciences Agronomiques du Rwanda, pp. 66-67.

[20] Ogola, B. O., Mathews, C. and Magongwa, S. M. 2013. The productivity of cassava-legume intercropping system in a dry environment in Nelspruit, South Africa. African Crop Science Conference Proceedings, Vol. 11.pp. 61-65.

[21] Oguzor, N. S. 2007. Effect of planting methods on growth of cassava. Research Journals of Biological Sciences 2: 590-592.

[22] Okigbo, B.N. 1982. Shifting cultivation in tropical Africa: Definition and Description. In: Proceeding of International Workshop on shifting cultivation. Bunting, A. H. and Bunting. E. (eds). PP: 18-36. FAO, Rome.

[23] Okonji, C. J., Okeleye, K. A., Olowe, V. I. O. \& Ajayi, E. O. 2007. Potentials of intercropping rice (Orysa sativa L.) and cassava (Manihotesculenta Crantz.) of different morphotypes inthe transition zone of South West Nigeria. International Journal of Agricultural Research 2 (5), 476-482.

[24] Papendick, R. I, Sanchez, P. A., Triplett, G. B. and Stelly, M. 1976. Multiple cropping. ASA, Special publication Madison, Wisconsin, USA, 376 PP.

[25] Polthanee, A., Wanapat, S., Wanapat, M. and Wachirapokorn, C. 2007. Cassava-Legumes inter-cropping: A potential foodfeed system for dairy farmers. Use of Cassava as Animal Feed, Khon Kaen University, Thailand. http://www.mekarn.org/procKK/polt.htm

[26] Prabhakar, M. and Pillai, N. G. 1984. Multiple cropping systems with tuber crops. Indian Farming, 33: 25-28.

[27] Sinclair, T. R. and Gardner, F. P. 1998. Principles of ecology in plant production. CAB ternational, Wallingford, UK. 